\title{
The Translation of Address Terms in Showing Politeness from Chinese into English
}

\section{Yu Chunli, Nor Shahila Mansor, Lay Hoon Ang \& Sharon Sharmini}

To Link this Article: http://dx.doi.org/10.6007/IJARBSS/v11-i12/11809

DOI:10.6007/IJARBSS/v11-i12/11809

Received: 08 October 2021, Revised: 11 November 2021, Accepted: 27 November 2021

Published Online: 19 December 2021

In-Text Citation: (Chunli et al., 2021)

To Cite this Article: Chunli, Y., Mansor, N. S., Ang, L. H., \& Sharmini, S. (2021). The Translation of Address Terms in Showing Politeness from Chinese into English. International Journal of Academic Research in Business and Social Sciences, 11(12), 2259-2275.

Copyright: (c) 2021 The Author(s)

Published by Human Resource Management Academic Research Society (www.hrmars.com)

This article is published under the Creative Commons Attribution (CC BY 4.0) license. Anyone may reproduce, distribute, translate and create derivative works of this article (for both commercial and non0-commercial purposes), subject to full attribution to the original publication and authors. The full terms of this license may be seen

at: http://creativecommons.org/licences/by/4.0/legalcode

Vol. 11, No. 12, 2021, Pg. 2259- 2275

http://hrmars.com/index.php/pages/detail/IJARBSS

JOURNAL HOMEPAGE

Full Terms \& Conditions of access and use can be found at http://hrmars.com/index.php/pages/detail/publication-ethics 


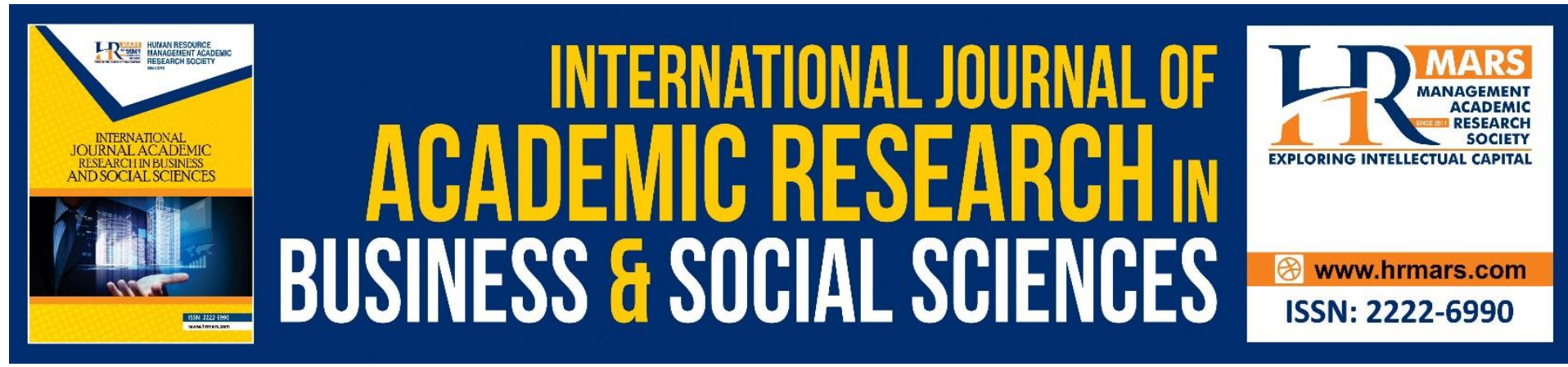

\title{
The Translation of Address Terms in Showing Politeness from Chinese into English
}

\author{
Yu Chunli, Nor Shahila Mansor, Lay Hoon Ang \& Sharon \\ Sharmini \\ Universiti Putra Malaysia (MALAYSIA)
}

\section{Abstract}

The proper translation of address terms plays a decisive role in the quality of translation practices. This paper explores the translation of Chinese address terms into English in showing politeness through a comparative analysis of the Chinese version Hong Lou Meng and its two famous English versions. It compares polite address terms in the two English versions A Dream of Red Mansions by Yang Hsien-yi \& Gladys Yang, and The Story of The Stone by David Hawkes \& John Minford respectively. The data for the study were sampled and collected from the three classic works. Hong Lou Meng is one of the four Chinese literary classics, which reflected the usage of Chinese address terms in an effective way. This study employs a descriptive qualitative research method. The analysis of address terms followed the framework of five politeness maxims in Chinese culture by Gu Yueguo (1992) based on the origin of Chinese culture. The findings suggest that address terms on politeness mostly reflected in "Selfdenigration Maxim" and "Address Maxim", while "Agreement Maxim" and "Maxim of Virtue" are usually displayed through a series of conversations and actions. The two main aspects, self-abasing terms, and honorifics, of polite address terms discussed in many prior studies are included in the self-denigration maxim. In addition, in some cases, some politeness is lost during the Chinese-English translation of address terms for the culture differences. The translators are suggested to probe into the implied meaning of the polite address terms under the suitable context instead of transferring the literal meaning directly in most cases. These findings not only offer some empirical data on polite address terms, but also contribute to the translation studies. Furthermore, this study will offer some implications on the further construction of the politeness principles on address terms.

Keywords: Chinese-English Translation, Address Terms, Five Politeness Maxims

\section{Introduction}

With the acceleration of culture exchanges among the world in various areas, the proper use of address term plays an increasingly important role on many occasions. When it comes to the proper use of address terms, it is essential for us to pay attention to the politeness of address terms. China is known as a country of etiquette (Yuxiang, 2019) with a long history and deep culture root. In Chinese culture, polite address terms usually contain two main components: self-abasing terms and honorifics (Chunling, 2015). Self-abasing terms refer to the humble addressing for oneself or oneself related person, while honorifics refer to 
respectful address terms when addressing others. The proper use of these address terms could better reflect one's respect for others.

Chinese politeness culture covers more than the above-mentioned aspects. Gu Yueguo (1992) suggested five politeness maxims based on Leech's theory of politeness, which takes into consideration the different aspects of Chinese culture. Therefore, this paper discussed the translation of polite address terms under the framework of five politeness maxims by Gu Yueguo (1992) by comparing the two English versions of the masterpiece A Dream of Red Mansions by Yang Hsien-yi \& GladysYang, and The Story of The Stone by David Hawkes \& John Minford separately in the hope of finding effective ways to convey the polite address terms properly.

The objectives of the study are as follows: 1 ) to explore the proper translation of polite address terms by comparing two well-known English versions of the famous novel Hong Lou Meng; 2 ) to examine the proper usage and translation of polite address terms based on $\mathrm{Gu}$ Yueguo's Politeness Principle.

\section{Literature Review}

\section{Previous Studies on Polite Address Terms}

Scholars have studied the translation of address terms on politeness among different languages. Ethelb (2015) investigated the translation of address terms in showing politeness from Arabic into English based on the data from the novel Madiq Alley. Resorting to the politeness theory by Brown and Levinson (1987), the study found that some patterns of facework were lost during the translation process, and the translation of relational terms of address is most challenging. Azin and Afghari (2015) analyzed Persian address terms based on politeness theory by Brown and Levinson (1987). The study mainly discussed positive and negative address terms based on positive and negative politeness. The findings showed that positive terms are more frequently used than negative terms. However, since Chinese and English belong to the different group of languages, the usage of address terms varies greatly from one another.

It has been pointed out that Chinese and English address terms are different in several ways. Lili and Jianqun (2019) discussed the different usage of Chinese and English address terms by comparing the different politeness cultures between China and the west. The study compared different usage of address term from four aspects, including kinship relation, address terms of titles, address terms of social relations and address terms of names. The authors concluded that the different politeness in address terms derived from different values, with people from English-speaking countries cherishing individual and assertive characteristics and the Chinese emphasizing collective and non-assertive characteristics.

From the previous studies we can learn that a systematic translation analysis of address terms from Chinese to English will enrich the address term study and translation study. Moreover, most studies on other languages are based on the western politeness theories. Considering the cultural differences between Chinese and English, the present study explores the proper usage of Chinese address terms translated into English in showing politeness based on five maxims on politeness suggested by Gu Yueguo (1992).

\section{Politeness in Chinese Culture}

In Chinese culture, "politeness" is translated into "limao"(礼貌), while "rite" into "li" (礼 ) in most cases. Although "politeness" is slightly different from "rite", "politeness" could find its historical origin from "rite" (Gu, 1990). Furthermore, according to the study by Lee (2020), 
the concept of politeness derives from two teachings of Confucianism, li and humility, among which, li is usually interpreted as "'ritual', 'ceremonial', 'etiquette', 'protocol', or good manners or conduct in a broader sense" (p.2). Since China is a country laying more emphasis on "li" (礼), it is necessary to retrospect its culture roots.

In a broad sense, "li" (礼) is usually translated as "rite". As to the origin of "rite", there are different opinions varying from sacrifice offering, religion, food to ritual ceremony, etc. (Yingjie, 2000; Haiying \& Wenwen, 2019). We must abide by the rite in different situations in our daily social activities. In addition, "Li" is the core value in the ideological system of Confucius (551 B.C. - 479 B.C.), which mainly covers three aspects: first, code of conduct for people's daily words and behaviors and the norms of external rituals; second, laws, regulations, and guidelines for state governance; and third, moral code for people's personal cultivation (Chunchun, 2019).

However, in a narrow sense, "li" could be interpreted as "politeness". According to The Book of Rites, compiled by Dai Sheng in the Western Han Dynasty (206 B.C.-A.D. 24), "li" was defined as "to humble yourself and show respect to others". Hence, in this retrospect, "politeness" or "limao" can be accepted as "li". The Book of Rites by Confucius and his seventy-two disciples was regarded as one of the six classics, which has exerted a great influence on the Chinese culture and traditions. Therefore, it is scientifically feasible to explore polite address terms in terms of self-abasing addressing and honorifics.

\section{Research Method}

\section{Sampling}

This study employs a qualitative method by comparing the source text (ST) with the two English versions of A Dream of Red Mansions by Yang Hsien-yi \& GladysYang and The Story of The Stone by David Hawkes and his son-in-law John Minford. The Chinese version Hong Lou Meng was written by Cao Xueqin and Gao E who lived in late Qing Dynasty. There are 120 chapters in this literary work in total. Since the last several chapters of the book had lost, the last 40 chapters were believed to be added by Gao E after Cao's death.

The literary work, Hong Lou Meng is one of the four great classical novels in China, which was usually compared to an encyclopedia of the Chinese feudal society encompassing abundant knowledge on medicine, cuisine, poetry, architecture and so on. The novel tells of the love story between Jia Baoyu, Lin Daiyu and Xue Baochai. Taking the tragedy of love and marriage between Jia Baoyu, Lin Daiyu and Xue Baochai as the main line, the novel depicts the rise and fall of four big families including Jia family, Wang family, Shi family and Xue family, which is set in the late Qing Dynasty. Based on the statistics by Baoyi (1989), there are 781 characters in this novel. Combined with 340 historical, mythological, legendary characters, the total characters amounted to 1121 . Therefore, the numerous characters in this novel ensured the abundance and variety of the data for this study.

\section{Instruments}

The tools used for collecting and extracting the data involve Snipaste 2.6.6-Beta, Microsoft Excel, and Pear OCR. Snipaste is a software used for capturing the pictures containing the key information of the data. Besides, Pear OCR is an online tool used for character recognition. Next, the format and characters will be adjusted and edited accordingly. The two instruments were mainly used for collecting the data on polite address terms. Additionally, Microsoft Excel was used to classify the data into five different tables based on the politeness framework established by Gu Yueguo (1992). The tables cover the 
following information, such as the source text (ST, Chinese version), target text one (TT1, the English version by Yang Hsien-yi and GladysYang), target text two (TT2, the English version by David Hawkes and John Minford), address terms in ST, TT1 and TT2 separately, annotations and so on.

\section{Data}

The data for this research were collected from the two English versions as well as its original Chinese version. The first 80 chapters of the second English version The Story of The Stone was translated by David Hawkes, while the last 40 Chapters of this version by John Minford. This study also compares the address terms used in English and Chinese versions to discuss the culture default on translating polite address terms.

As to the process for carrying out the research, first and foremost, relative Chinese address terms were collected by putting the Chinese version and two relevant English versions into tables for polite address terms. Additionally, the whole conversation will be recorded to understand the context. In addition, a deep analysis is provided to discuss the translation strategies, the difficulties and culture default during the translation process. To conclude, the paper explores possible ways to deal with this phenomenon.

\section{Theoretical Framework}

The data for this study were classified under the framework by Gu Yueguo (1992) who has summarized five politeness principles based on the analysis of Chinese culture. Gu compared the differences between "li" and "limao" by tracing back to the Chinese classical works The Analects of Confucius and The Book of Rites.

In his study, five maxims concerning politeness are concluded: "self-denigration maxim, address term maxim, refinement maxim, agreement maxim and maxim of virtue" (p. 80). Firstly, self-denigration maxim includes denigrate self and elevate others, which is a common way in ancient Chinese address system to show one's modesty and respect for others. Secondly, address term maxim mainly contains two aspects: 1 ) the addresser's recognition of the addressee's social status as a social being; 2) the addresser's perception of the social relation between the addressee. Thirdly, refinement maxim also covers two aspects, including 1) choose elegant language and forbid profanity; and 2) use more euphemism than bluntness. Fourthly, agreement maxim focuses more on the face culture. For one thing, the speaker's face ought to be considered when one is doing a kind deed by extending an invitation, offering something to or asking for something from the listener; 2) For another, the listener's face should be attended to when criticizing the listener. The agreement maxim should be resorted to deal with the above-mentioned two cases. With regard to case one, the listener is expected to agree with the speaker to save the speaker's face to the best of the listener's ability in most circumstances. Meanwhile, in terms of case two, the speaker is expected to praise the listeners before blaming them or expressing disagreement with the listeners. Fifthly, maxim of virtue could be reflected from two facets: words and behaviour. In terms of words, the speakers tend to exaggerate the listeners' benefits and minimize their own efforts. Moreover, in terms of behaviour, the speakers would try to minimize the cost to others and increase the benefits to others. This study will explore the translation of polite address terms from the five maxims by analyzing the examples chosen from A Dream of Red Mansions.

\section{Findings}

Various types of address terms in showing politeness have been found in this classical 
work. This study analyzed the translation of these address terms from Chinese into English in the hope of perfecting translation practice and promoting culture exchanges. The English version by Yang Hsien-yi and GladysYang is named as A Dream of Red Mansions, while the English version by David Hawkes \& John Minford is titled as The Story of the Stone.

\section{Self-denigration Maxim}

In this maxim, according to Gu Yueguo (1992), two aspects are highlighted including 1) denigrate self; and 2) elevate other. There are quite a lot of examples in this classic literary work. Several representative examples in Chinese and their translated English versions were selected and compared to show the proper transformation of address terms in showing politeness.

Example 1

ST: 当下雨村见了士隐, 忙施礼陪笑道: “老先生倚门仁望, 敢是街市上有甚新闻否?"士隐笑 道:“非也。适因小女啼哭,引他出来作要, 正是无聊之甚, 兄来得正妙, 请入小斋 一谈, 彼此皆可消此永昼。”说着, 便令人送女儿进去, 自与雨村携手来至书房中

TT1: Having greeted Shih-yin, Yucun asked, "What are you watching from your gate, sir? Is there any news in town?" "Nothing," was the reply. "My little girl was crying, so I brought her out to play. You couldn't have arrived at a better moment, as I was feeling thoroughly bored. Come in and help me while away the long summer day."

TT2: 'No, no,' said Shi-yin.'It just happened that my little girl was crying, so I brought her out here to amuse her. Your coming is most opportune, dear boy. I was beginning to feel most dreadfully bored. Won't you come into my little den, and we can help each other to while away this tedious hot day?'

In Example 1, the father Zhen Shiyin was walking along the street to amuse his baby girl. “小女” (xiaonv) was translated into "my little girl” in both the two English versions. This usage of this address term in Chinese conforms to the self-denigration maxim to show one's politeness and respect to the other side. In fact, in most cases, these terms could be translated into "my daughter" directly. Since here it refers to Zhen Yinglian, a baby girl who was three years old at that time. Therefore, the two English versions are acceptable here, which is suitable for this context.

Example 2

ST:如海乃说:“已择了出月初二日小女入都, 尊兄即同路而往,岂不两便?"雨村唯唯听命 , 心中十分得意。如海遂打点礼物并饯行之事, 雨村一一领了。

TT1: "I've chosen the second day of next month for my daughter's departure for the capital," continued Ruhai. "It would suit both parties, surely, if you were to travel together?"Yutsun promptly agreed with the greatest satisfaction and took the gifts and travelling expenses which Ju-hai had prepared.

TT2:'I have fixed the second day of next month for my little girl's journey to the capital,' said Ru-hai. 'If you cared to travel with her, it would be convenient for both of us.'Yu-cun accepted the suggestion with eager deference. Everything, he thought to himself, was turning out very satisfactorily. Ru-hai for his part set about preparing presents for his 
wife's family and parting gifts for Yu-cun, all of which Yu-cun in due course took charge of.

In Example 2, “小女” (xiao nv) was translated into "my daughter" by Yang Hsien-yi and GladysYang in the first English version, which might be more acceptable, for the word “小女 " (xiao nv) here refers to Lin Daiyu who is already a girl in her teenage years. However, in the second English version, David Hawkes translated “小女” (xiao nv) into "my little girl”. In fact, in Chinese culture, this is a way to show politeness by denigrating one's own related people or items. Therefore, the word “小女” is used by Lin Ruhai, the father of Lin Daiyu, mainly to show his politeness to the addressee by lowering the status of his own daughter. The Chinese character “小" (xiao) is not always equivalent to its English equivalents "small" or "little" in Chinese polite culture. Because in this circumstance, this character was not used for its literal meaning. Hence, it is inappropriate to translate it into "my little girl" in the second version by David Hawkes.

Additionally, in Example 2, another polite address term was used, that is “尊兄” (zun xiong). According to the literary meaning, it indicates "respectable brother". In fact, in this context, “尊兄” (zun xiong) was used by Lin Ruhai (Lin Daiyu's father) to address Jia Yucun, Lin Daiyu's teacher. Therefore, we can learn that the addressee is not really the speaker's elder brother. In other words, they have no blood ties. According to the New Century ChineseEnglish Dictionary (2003), the term “兄” (xiong) could be used as a polite expression, which is “used between men". For example, there are several similar polite expressions like: “老兄” (lao xiong), “仁兄” (ren xiong), “兄长” (xiong zhang), etc.

The term used here was to show Lin Ruhai's respect and politeness for Jia Yucun. Therefore, it made no sense if translated into "respectable brother", which might cause misunderstanding. It is a typical usage of showing politeness by elevating others. Both two English versions have translated it into pronoun "you", which is easy to understand but to some extent failed to show the politeness in English.

Example 3

ST: 次日,面谋之如海。如海道: “天缘凑巧, 因贱荆去世,都中家岳母念及小女无人依傍教 育, 前已遣了男女船只来接, 因小女未曾大痊, 故末及行。

TT1:The next day he laid his case before Lin Ruhai. "What a lucky coincidence!" exclaimed Ruhai. "Since my wife's death my mother-in-law in the capital has been worried because my daughter has no one to bring her up. She has sent two boats with male and female attendants to fetch the child, but I delayed her departure while she was unwell.

TT2:'It so happens that an opportunity of helping you has just presented itself,' said Ru-hai. Since my poor wife passed on, my mother-in-law in the capital has been worried about the little girl having no one to look after her and has already sent some of her folk here by barge to fetch her away. The only reason she has so far not gone is that she has not been quite recovered from her illness.

In ancient Chinese, “贱㣜” (jian jing) refers to one's wife, which is a kind of way in ancient Chinese to show one's politeness by denigrating self-related people or items. In Example 3, “ 贱㓫” (jian jing) in the original text refers to Lin Ruhai's wife who is also the main character 
Lin Daiyu's mother. Yang's version has translated “贱㣜” (jian jing) into "my wife", which is quite acceptable, while in David Hawkes's English version, it has been translated into "my poor wife". In fact, it is a kind of misunderstanding of cultural-loaded words. According to the New Century Chinese-English Dictionary (2003), “贱” (jian) has three meanings: “1) lowpriced, inexpensive or cheap; 2) lowly, humble; 3) low-down; base; despicable; 4) (modest) my" (p.776). Although the word “贱” (jian) also has the meaning of "lowly" or "poor", the term here is used just to indicate self-related people or items. Therefore, in this case, Yang's English version is more acceptable for this address term.

Example 4

$\mathrm{ST}$ :若问那赦公, 也有二子, 长名贾琖, 今已二十来往了, 亲上作亲, 娶的就是政老爹 夫人王氏之内侄女, 今已娶了二年。这位琏爷身上现捐的是个同知, 也是不肯读 书, 于世路上好机变, 言谈去的, 所以如今只在乃叔政老爷家住着, 帮着料理些 家务。谁知自娶了他令夫人之后, 倒上下无一人不称颂他夫人的, 琏爷倒退了一 射之地：说模样又极标致, 言谈又爽利, 心机又极深细, 竟是个男人万不及一的

TT1: Jia She has two sons as well. Jia Lian, the elder, is over twenty now. Two years ago, he married a relative, the niece of Jia Zheng's wife Lady Wang. This Jia Lian, who has bought the rank of a sub-prefect, takes no interest in books but is a smooth man of the world, so he lives with his uncle Jia Zheng and helps him to manage his domestic affairs. Since his marriage he's been thrown into the shade by his wife, who is praised by everybody high and low. I hear she's extremely good-looking and a clever talker. So resourceful and astute that not a man in ten thousand is a match for her."

TT2: But you were asking about Sir She. Yes, he has a son too, called Jia Lian. He' s already a young man in his early twenties. He married his own kin, the niece of his Uncle Zheng's wife, Lady Wang. He's been married now for four or five years. Holds the rank of a Subperfect by purchase. He's another member of the family who doesn't find responsibilities congenial. He knows his way around, though, and has a great gift of the gab, so at present he stays at home with his Uncle Zheng and helps him manage the family's affairs. However, ever since he married this young lady I mentioned, everyone high and low has joined in praising her, and he has been put into the shade rather. She is not only a very handsome young woman, she also has a very ready tongue and a very good head -more than a match for most men, I can tell you.

In this example, “他令夫人” (ta ling fu ren) was used to indicate Jialian's wife. This excerpt was said by Leng Zixing, an antiquary who described Jialian to Jia Yucun. Based on the New Century Chinese-English Dictionary (2003), it is a polite expression which means "your". Some examples are listed as follows: 
Table 1 Some Polite Expressions about “令”(ling, an honorific term meaning "your”)

\begin{tabular}{|c|l|}
\hline 令尊 & Your father \\
\hline 令堂 & Your mother \\
\hline 令爱/令媛 & Your daughter \\
\hline 令郎 & Your son \\
\hline 令妹 & Your sister \\
\hline 令兄 & Your brother \\
\hline 令亲 & Your relative/your relation \\
\hline
\end{tabular}

In Yang's version, the term “他令夫人” (ta ling fu ren) was not translated directly. Instead, it used "his marriage". Combined with the next term “他夫人” (ta fu ren), this version used "his wife". And in David Hawkes's version “他令夫人” (ta ling fu ren) was translated into "this young lady I mentioned". Since this sentence was said from the third-party perspective, both the two versions could interpret the source text to the readers effectively.

Example 5

ST:

水溶见他语言清楚, 谈吐有致, 一面又向贾政笑道：“令郎真乃龙驹凤雏，非小王 在世翁前唐突, 将来“雏凤清于老凤声”，未可量也。”贾政忙陪笑道：“犬子岂 敢谬承金奖。赖藩郡馀祯, 果如是言, 亦荫生辈之幸矣。”

TT1 : The clarity and fluency of Pao-yu's answers made the prince turn to observe to Chia Cheng, "Your son is truly a dragon's colt or young phoenix. May I venture to predict that in time to come this young phoenix may even surpass the old one?" "My worthless son does not deserve such high praise," rejoined Chia Cheng hurriedly with a courteous Emile. "If thanks to the grace of Your Highness such proves the case, that will be our good fortune."

TT2 : Delighted that everything Bao-yu said was so clear and to the point, the prince observed to Jia Zheng that'the young phoenix was worthy of his sire'.'I trust I shall not offend you by saying so to your face,' he said, 'but I venture to prophesy that this fledgling of yours will one day "sing sweeter than the parent bird".' Jia Zheng smiled politely. 'My son is doubtless unworthy of the compliment. Your Highness is good enough to pay him. If; thanks to your encouragement, he turns out as you say, we shall count ourselves truly fortunate.'

In Example 5, “令郎” (ling lang) is an honorific to address the hearer's son to show the addresser's politeness and respect. Meanwhile, “犬子”(quan zi) was also used in the same conversation to show the addresser's modesty.

In TT1, “令郎”(ling lang) was translated into "your son". But to some extent, the politeness has lost in the target language. In TT2, “令郎”(ling lang) was translated into "the young phoenix" combined with other information “龙驹凤维” (lóng jū fèng chú), which is also a compliment word indicating young talented scholars. 
As to "犬子" (quan zi), in TT1, it was translated into "my worthless son"; while in TT2, it was translated into "my son" directly. In fact, “犬子" (quan zi) is just a self-abasing addressing to show one's modesty. Actually, it does not mean "worthless". According to the New Century Chinese-English Dictionary (2003:1337), “犬子" (quan zi) is a modest term meaning "my son". Therefore, compared with TT1, "my son" in TT2 would be more appropriate.

\section{Address Term Maxim}

In this maxim, according to $\mathrm{Gu}$ (1992), address term system includes single address terms and compound address terms. Twelve factors are considered under the framework of linguistics, such as kinship, position, status, familiarity, gender, age, occasion, etc.

\section{Example 6}

$\mathrm{ST}$ :元妃便向贾母道：“近日身上可好?”贾母扶着小Y头，颤颤巍巍站起来，答应道 : “ 托娘娘洪福, 起居尚健。”

TT1:"How has your health been recently?" she asked her grandmother. The old lady stood up, leaning on her maid's arm."By grace of Your Highness, my health is still good."

TT2: She spoke first to Grandmother Jia:'Have you been keeping well?'

Leaning on her maid, the old lady rose shakily to her feet and replied:'Thanks to Your Grace's beneficent aura I am still in good health.'

In Example 6, “娘娘” (niang niang) was used by Grandmother Jia to address her granddaughter, Consort Yuan (Yuanchun), who was a consort of the emperor. This conversation was taken place when the Jia family went to the palace to visit Consort Yuan. There are a lot of etiquette to be followed in the palace. Therefore, Grandmother Jia chose to use the address terms reflecting social status in such an official occasion. In fact, according to the seniority in the family, Yuanchun should address Grandmother Jia as "Grandma".

This example reveals the "Address Term Maxim" of politeness in the official occasion regardless of their age and seniority in the family. Therefore, both the two versions are acceptable by employing the official title of the imperial family.

\section{Refinement Maxim}

Firstly, this maxim means using some elegant words or expressions instead of using the rude words to show one's politeness.

In addition, this maxim also refers to the use of euphemism to avoid embarrassment or unpleasantness.

\section{Example 7}

ST:黛玉道:“既然定要起诗社,咱们都是诗翁了,先把这些姐妹叔嫂的字样改了才不俗。” 李纳道:“极是,何不大家起个别号,彼此称呼则雅。我是定了“稻香老农”, 再无人占 的。”探春笑道:“我就是 ‘秋爽居士'罢。”

TT1:"If you're set on starting a poetry club," aid Tai-yu, "we must all be poets. And first, to be less conventional, we must stop calling each other 'sister,' 'cousin, 'sister-in-law' and so forth."'Quite right," agreed Li Wan. "Let's choose some elegant pen-names. I'll be The Old Peasant of Sweet Paddy. No one else can have that name,"'I'll be Master of Autumn 
Freshness," cried Tan-chun.

TT2: 'If we are definitely going to have a poetry club,' said Dai-yu, 'then as members of the club we are all equals and fellow-poets. We can't go on calling ourselves "cousin" and "sister-in-law" all the time;'

'I quite agree,' said Li Wan. 'We ought to choose pen-names to sign our poems with, then we can use them for addressing each other by as well. I shall call myself "Farmer Sweetrice". I don't suppose anyone else will want that title.'

'I shall call myself "Autumn Studio",' said Tan-chun.

In Example 7, Daiyu, Li Wan and Tanchun etc. were planning to set up a poetry club. Daiyu proposed to think of some elegant names instead of using "brother", "sister" to call each other as before. In the source text, Li Wan mentioned that the pen names might make their addressing to each other sound more elegant. Thus, to some extent, these address terms conform to refinement address terms. The C-E of the two versions for these terms are listed as follows:

Table 2 Elegant Names for the Poetry Club

\begin{tabular}{|c|c|c|c|}
\hline $\begin{array}{r}\text { ST } \\
\text { (Name) }\end{array}$ & $\begin{array}{l}\text { New Address } \\
\text { Term }\end{array}$ & TT1 & TT2 \\
\hline 李纨 & 稻香老农 & $\begin{array}{l}\text { The Old Peasant of Sweet } \\
\text { Paddy }\end{array}$ & $\begin{array}{l}\text { Farmer-sweet } \\
\text { rice }\end{array}$ \\
\hline \multirow[t]{2}{*}{ 探春 } & 秋爽居士 & $\begin{array}{l}\text { Master of Autumn } \\
\text { Freshness }\end{array}$ & Autumn Studio \\
\hline & 蕉下客 & $\begin{array}{l}\text { The Stranger Under the } \\
\text { Plantain }\end{array}$ & $\begin{array}{l}\text { Under the } \\
\text { Plantains }\end{array}$ \\
\hline 黛玉 & 潇湘妃子 & Queen of the Bamboos & River Queen \\
\hline 薛宝 & 蘅芜君 & Lady of the Alpinia & Lady All-spice \\
\hline \multirow{3}{*}{ 玉 贾宝 } & 绛洞花主 & $\begin{array}{l}\text { Prince of the Crimson } \\
\text { Cavern }\end{array}$ & $\begin{array}{l}\text { Lord of the } \\
\text { Flowers }\end{array}$ \\
\hline & 富贵闲人 & The Rich and Noble Idler & Lucky Lounger \\
\hline & 怡红公子 & The Happy Red Prince & Green Boy \\
\hline 迎春 & 菱洲 & Mistress of Caltrop Isle & $\begin{array}{l}\text { Amaryllis } \\
\text { Islander }\end{array}$ \\
\hline 惜春 & 藕榭 & Mistress of Lotus Pavilion & Lotus Dweller \\
\hline
\end{tabular}

As we can see, in this example, most elegant new terms are based on their names of residence.

TT1 had taken the features of their residence into consideration. For example, “㴋湘妃 子” (xiao xiang fei zi, Consort Xiaoxiang) in the ST was translated into "Queen of the bamboos”. Literally, it is difficult to connect “潇湘” (xiao xiang) with bamboos. Actually, “潚 湘妃子" derives from an allusion during the period of Shun. It is said that the two daughters 
“娥皇” (E huang) and “女英” (nv ying) of Emperor Yao became the consorts of Emperor Shun. Hearing the news that their husband was killed in the battlefield, the two sisters wept leaning against the bamboos day and night expecting their husband's return. The bamboos was named as “湘妃竹” (pronounce xiang fei zhu, Consort Xiang Bamboo) for their tears speckled on the bamboo never fade away. At last, E huang and Nv Ying threw themselves into the Xiangjiang river (湘江) after crying bitterly and desperately. Lin Daiyu's residence was surrounded by bamboos, a kind of plant always symbolize the lofty and pure personality of Lin Daiyu. Therefore, bearing in mind the feature of her residence and the symbolic meaning of "bamboo", you would find the elegant name suits her well. Furthermore, this elegant address term coming from the allusion also implied the tragic love story between Jia Baoyu and Lin Daiyu.

TT2 had noticed the culture difference between Chinese and English. As to the translation of “怡红公子” (yi hong gong zi), instead of translating “红” (hong, literal meaning "red") into "red" directly, David Hawkes used the opposite "green" of the source word "red". "Green" represents "young" and "flourishing" in the target culture, while "red" usually refers to violence and blood in the English culture. Thus, by resorting to the strategy of domestication, the translator successfully realized cultural substitution.

\section{Agreement Maxim}

Based on the Chinese "face culture", politeness is a useful face-saver for two sides. Two main aspects are concluded by Gu for this maxim:

1) Praise before criticize.

2) Try to agree with other's opinion or satisfy their request to show one's respect.

In the first aspect, the speakers will first find something they agreed with before criticizing the listeners. Considering the listeners' face and feelings, the speakers' action seem more polite, which will be more likely to be accepted by the listeners. As for the second aspect, it means that when it comes to invitation and request, the listeners tend to accept the speakers' kindness to show their politeness in most cases. According to $\mathrm{Gu}$, this maxim is usually realized through a series of conversation leading to a certain action.

\section{Example 8}

ST: 刚进了园, 就有几个Y髻来找他, 一同到了红香固中。只见䇥开玳瑁, 裖设芙蓉 。众人都笑：“寿星全了。”上面四座定要让他们四个人坐, 四人皆不肯。薛姨 妈说：“我老天拔地, 又不合你们的群儿, 我倒觉拘的慌, 不如我到厅上随便躺 躺去倒好。我又吃不下什么去, 又不大吃酒, 这里让他们倒便宜。”尤氏等执意 不从。宝钗道：“这也罢了, 倒是让妈在厅上歪着自如些, 有爱吃的送些过去, 倒自在了。且前头没人在那里, 又可照看了。”探春等笑道 : “既这样, 恭敬不 如从命。”因大家送了他到议事厅上, 眼看着命Y头们铺了一个锦裖并靠背引枕 之类, 又嘱咐：“好生给姨妈捶腿, 要茶要水别推三扯四的。回来送了东西来, 姨妈吃了就赏你们吃。只别离了这里出去。”小Y头们都答应了。

TT1: As soon as she entered it, she was met by several maids who had come to fetch her. They escorted her to Red Fragrance Farm where a sumptuous feast had been spread."Now all 
the birthday stars are here," cried the others laughingly. They insisted that these four must take the seats of honour, but this they declined to do. Aunt Hsueh declared, "I'm too old to mix in your crowd, and I feel very boxed up here too. I'd rather lie-down in comfort in the Council Hall. I can't eat anything or drink much either.so I'll leave my place to them and that will suit everybody."At first Madam Yu and the rest would not hear of this, but Pao-chai said, "That's all right. Why not let mother lie down in the hall where she can relax? We can send over any dishes she likes. She'll feel freer. Besides, there's nobody in front today, and she can keep an eye on things."'In that case," agreed Tanchun, "we'd better do as she asks instead of standing on ceremony."

So they saw Aunt Hsueh to the hall, told the young maids to spread a silk mattress, backrest and pillows for Her,.and instructed them:"Mind you look after Madam Hsueh well. Massage her legs, serve her tea and don't shirk your work. We'll be sending food over later, and after she's eaten you can have what's left. But you mustn't leave this place."The young maids promised to carry out these orders.

TT2:A number of maids who had been sent out by the others to look for her took charge of her as she entered it and carried her off to the summerhouse. It was a dazzling sight there that met her eyes: not perhaps the chelonian tables, lotus-cushioned chairs of the poet; but no effort had been spared to make it an eye-catching and appetizing spread. A friendly laugh greeted her arrival. 'Now all the birthday folk are here!' They wanted to make her and the other three-Bao-yu, Bao-qin and Xiu-yan - sit at the head of the feast, but as Aunt Xue was present, all four of them naturally refused. 'A slow old buffer like me is no fit company for you young people,'said Aunt Xue. 'I should only feel uncomfortable if I stayed. Let me go and lie down in the jobs room. I don't feel like eating anything and I'm not much of a drinker. You will be much better able to look after your guests if I am not here.' You-shi and the others loudly insisted that she should stay. Only Bao-chai dissented.'Whether or not we should get on better without Mamma,' she said, ' $I$ ' $m$ sure Mamma herself would be happier lying down in the jobs room than sitting here with us. If there is anything here she fancies, we can have it sent over to her and she will be able to eat it there on her own in comfort. Besides, there is no one in charge there at the moment. If Mamma is there, she will be able to keep an eye on things.' 'Oh well, in that case we'll let her go,' said Tan-chun smiling. 'Obedience is the best obeisance, as they say.' She went with the others to escort her aunt to the jobs room and personally supervised the arrangement of various pillows and cushions by the junior maids. 'Now,' she said to these junior maids when Aunt Xue had been comfortably settled, 'if you will stay here and massage Mrs Xue's legs for her and fetch her tea or anything when she asks you without making up all sorts of wonderful excuses, I shouldn't be surprised if later on, when we send some nice things for her to eat, she doesn't give some of them to you. So mind you don't go away!' The girls all promised that they would stay.

This example reflected agreement maxim. In this example, Jia Baoyu, Xue Baoqin, Xing Xiuyan and Pingerh were going to celebrate their birthdays. Since other elders were not at home for attending a funeral, Tan Chun intended to invite Aunt Xue to participate, but she refused for fear of uneasiness being with so many younsters by requesting to stay in the Council Hall. Under the persuasion of Bao Chai, Tan Chun agreed with her at last.

"Agreement maxim" was well reflected in this context. According to Gu's agreement maxim, when inviting others, not fulfilling the invitee's requirement was kind of face- 
threatening act. Therefore, in this context, Tan Chun finally agreed with Aunt Xue's request, claiming that 'Obedience is the best obeisance'.

As to the address terms under this maxim, “姨妈” (yi ma, the literal meaning is 'aunt' ) was used by Tan Chun in this conversation. Firstly, “姨妈”(yi ma, meaning “aunt") refers to Bao Chai's mother, who is also Baoyu's aunt. Although Tan Chun and Aunt Xue does not have blood ties. According to seniority, it is appropriate to call her "aunt". However, the term "姨 妈” (yi ma) was translated into "Madam Hsueh"; and in TT2 "Mrs Xue". Taking the politeness culture of source language (Chinese) and the context into consideration, it is advised to translate “姨妈” (yi ma) into “Aunt Xue”, which is more equivalent to ST as well as suitable for this context.

\section{Maxim of Virtue}

Maxim of virtue is a common way to show politeness in Chinese culture. The maxim is usually used when asking or doing sb. a favor. Two factors are emphasized for this maxim: words and deeds.

This maxim includes two main aspects:

1) action motivation: try to minimize others' efforts while at the same time increase the benefits for them;

2) language aspect: try to exaggerate others' kindness while minimize their own efforts (p.14).

Example 9

ST: 那刘姥姥先听见告艰难, 只当是没有, 心里便突突的; 后来听见给他二十两, 喜的又浑身发痒起来, 说道: “喛, 我也是知道艰难的。但俗语说的“瘦死的 骆驼比马大”, 凭他怎样, 你老拔根寒毛比我们的腰还粗呢! ”周瑞家的见他 说的粗鄙, 只管使眼色止他。凤姐看见, 笑而不睬, 只命平儿把昨儿那包银 子拿来, 再拿一吊钱来, 都送到刘姥姥的跟前。凤姐乃道: “这是二十两银子 , 暂且给这孩子做件冬衣罢。若不拿着, 就真是怪我了。这钱雇车坐罢。改 日无事, 只管来逛逛, 方是亲戚们的意思。天也晚了, 也不虚留你们了, 到 家里该问好的问个好儿罢。”一面说, 一面就站了起来。

TT1:Talk of difficulties had dashed all Granny Liu's hopes and set her heart palpitating. The promise of twenty taels put her in a flutter of joy."Ah," she cried, "1 know what difficulties are. But 'A starved camel is bigger than a horse' No matter how, 'A hair from your body is thicker than our waist,' "Mrs. Chou kept signalling to her mot to talk in this crude way, but Hsi-feng merely laughed and seemed not to mind. She sent Ping-erh for the package of silver and a string of cash and presented these to the old woman." Here's twenty taels to make the child some winter clothes. If you refuse it, I shall think you're offended. With the cash you can hire a cart. When you've time, drop in again as relatives should. It's growing late, I won't keep you for no purpose. Give my compliments to everyone at home to whom I should be remembered. 
TT2 : When Grannie Liu heard Xi-feng talk about 'difficulties' she concluded that there was no hope. Her delight and the way in which her face lit up with pleasure when she heard that she was, after all, to be given twenty taels of sliver can be imagined.'We knew you had your troubles,' she said, 'but as the saying goes, "A starved camel is bigger than a fat horse." Say what you like, a hair plucked from your arm is thicker than a man's waist to folks like us!'

Horrified by the crudity of these expressions, Zhou Rui's wife, who was standing by, was meanwhile signaling frantically to the old lady to stop. But Xi-feng laughed quite unconcernedly and told Patience to wrap up the silver and also to fetch a string of cash to go with it. The money was set down in front of Grannie Liu. 'Here is the twenty taels of silver,' said Xi-feng. 'Take this for the time being to make some winter clothes for the children with. Some time later on, when you have nothing better to do, look in on us for a day or two for kinship's sake. It's late now, so I won't try to keep you. Give our regards to everybody who ought to be remembered when you get back!'

This example reveals the maxim of virtue. This part described Wang Xifeng gave 20 taels to Granny Liu, who came to Jia Mansion for help. At first, Wang Xifeng described the difficulties the big family faced. Granny Liu had thought that she and her grandson might have to go back home empty-handed after hearing Wang Xiafeng's modest words. Upon hearing Mrs Wang's giving her 20 taels at last, Granny Liu felt overjoyed. Because it means quite a lot of money for Granny Liu who lives in the countryside, although it is very little for a big wealthy Jia family.

Granny Liu firstly expressed her gratitude to Wang Xifeng by exaggerating her favor using a saying "A starved camel is bigger than a fat horse", while Wang tried to minimize her favor for Granny Liu by advising her to make a winter clothes for her grandson, whose subaudition was that the money was not so much. Based on the two aspects, this conversation could reflect the maxim of virtue.

The address term used here by Granny Liu to address Wang Xifeng is “你老” (ni lao), the literal meaning of which is "you old". Although Wang Xifeng is not older than Granny Liu, it was a kind of politeness to address the one whose social status is higher than the addresser. "老" (lao) used here had nothing to do with age. Instead, it was used here by Granny Liu to show respect for Wang. It was translated into your (arm/body) combined with other words. To some extent, the politeness could not be conveyed in the target text just through the word "your", whose equivalent word in Chinese is usually “你的” (ni de) or “你们的” (ni men de).

\section{Discussion}

In this study, polite address terms have been investigated under the five maxims by Gu Yueguo (1992). Consistent with prior studies, several polite address terms were identified under the self-denigration maxim, for this maxim covers the two main types of polite address terms: self-abasing terms and honorifics. For example, The terms “小” (xiao), “贱” (jian), “犬 " (quan), etc. were usually found in many self-abasing terms, which mostly indicate "little", "poor" or "low"; while the terms indicating "fine" or "respect" like “令” (ling), “尊” (zun), “老 " (lao), etc. were mostly used in honorifics.

Furthermore, address term maxim is another maxim to show one's politeness in terms of social relation. The proper usage of address terms in view of occasion, one's occupation, 
age, gender, familiarity, etc. could better convey one's politeness. For instance, In formal occasion, Grandma Jia chose to use social terms “娘娘” (niang niang, meaning “consort") to address her granddaughter, Jia Yuanchun. In this respect, politeness was better conveyed.

In this study, it was found that refinement maxim was reflected from the elegant address terms used for the poetry club. Actually, euphemism is another important aspects under this maxim, such as using the word “殁” (mo), “逝世” (shi shi), “仙逝” (xian shi) instead of using the term “死” (si, meaning 'die') directly. However, address terms in this respect are not obviously reflected in this study.

In addition, the study also examined the address terms used under agreement maxim and maxim of virtue, the two of which are usually achieved through a series of actions. “姨妈 " (yi ma, meaning “aunt") and “你老” (ni lao) was discussed in the two maxims, which showed the respect of the speaker to the addressee.

\section{Conclusion}

This study analyzed the translation of address terms on politeness from the perspective of Gu Yueguo's politeness principle by comparing the two representative English versions: $A$ Dream of Red Mansions and The Story of The Stone. The proper translation of address terms is of great significance in culture exchanges. The translators must pay attention to the politeness culture of the languages during the translation process to ensure the accurate convey of the information.

By analyzing the representative polite address terms in one of the Chinese classical works, the study shows that the mostly used maxims for analyzing the address terms on politeness are "Self-denigration Maxim" and "Address Maxim", while "Agreement Maxim" and "Maxim of Virtue" are usually reflected through one's behaviour. The two main aspects, self-abasing terms, and honorifics, of polite address terms discussed in many prior studies are included in the self-denigration maxim. Using address terms properly under the address term maxim could also show one's respect and politeness. These findings not only could offer some empirical data on polite address terms, but also contribute to the translation studies.

This study examined the translation of address terms on politeness from Chinese into English based on the five politeness maxims by Gu Yueguo, which are most suitable for analyzing the politeness phenomenon under the suitable context of Chinese culture. First and foremost, this study will enrich the empirical data on polite address terms by offering some examples in one of the Chinese classic works. Furthermore, the comparison and discussion of translating polite address terms in the two representative English versions of Hong Lou Meng will help improve the quality of later translation practice. In addition, this study will help optimize the existing politeness theory and contribute to the further construction of the politeness principles on address terms. 


\section{References}

Azin, N., \& Afghari, A. (2015). The study of Persian address terms in young adult novels according to the politeness theory. Mediterranean Journal of Social Sciences, 6(5), 438438.

Braun, F. (1988). Terms of address. Berlin: Mouton de Gruyter.

Ethelb, H. (2015). Using address terms in showing politeness with reference to their translation from Arabic into English. International Journal of Comparative Literature \& Translation Studies, 3(3). 27-37.

Geng, C. (2015). Comparison between Chinese address terms and English address terms. Higher Education of Social Science, 9(4),1-4.

Yueguo, G. (1990). Politeness phenomena in modern Chinese. Journal of Pragmatics. 14(2): 237-257.

Yueguo, G. (1992). Politeness, Pragmatics and Culture [J]. Foreign Language Teaching and Research, (04):10-17+80.

Chunchun, H. (2019). Study on Confucius' Ritual Thought (Master's degree thesis, Guangxi Normal University).

Yu, H. (2002). New Century Chinese-English Dictionary. Beijing: Foreign Language Teaching and Research Press.

Lee, H. Y. (2020). Linguistic Politeness in the Chinese Language and Culture. Theory and Practice in Language Studies, 10 (1), 1-9.

Leech, G. N. (1983). Principles of Pragmatics. London/New York: Longman.

Lili, Z., \& Jianqun, Z. (2019). The Influences of Cultural Different Politeness on the use of address terms in Chinese and in English Discourse. Journal of Humanities and Education Development (JHED), 1(5), 243-249.

Widarwati, N. T. (2014). Politeness Strategies and Linguistic politeness Markers of Imperative In The Very Best of Donald Duck Comic Series And Their Translation In Indonesian. Prasasti: Journal of Linguistics, 3(1).

Xueqin, C., \& Gao, E. (1994). A Dream of Red Mansions. Translated by Yang Hsien-Yi and Gladys Yang. Foreign Languages Press. Beijing. China.

Xueqin, C., \& Gao, E. (1973). The Story of the Stone: A Chinese Novel in Five Volumes. Translated by David Hawkes and John Minford. Penguin Group.

Xueqin, C., \& Gao, E. (Qing Dynasty).(2005 reprint). A Dream of Red Mansion. 2 Ed. Beijing: People's Literature Publishing House.

Yingjie, Y. (2000). A Further Study of the Origin of "Rite" [J]. Journal of Liaoning Normal University, (6):91-94.

Yuxiang, Х. (2019). Chinese Humble Language in Cultural Background. МОВА I КУЛЬТУРА, 478. 